\title{
FAMILY MORBIDITY
}

\section{A SUGGESTED METHOD OF MEASUREMENT}

\author{
BY \\ JACOB COHEN, JACOB YOFE, AND A. MICHAEL DAVIES \\ Ministry of Health and Department of Preventive Medicine, Hebrew University-Hadassah \\ Medical School, Jerusalem, Israel
}

It is usual to regard the family as a unit with specific attributes rather than as an aggregate of individuals with unrelated attributes. Is this view justified with regard to morbidity? Has a family a constant trend over the years?

The present paper demonstrates a method which may help to answer these questions. It is based on the measurement of morbidity as reflected in consultations with physicians and is exemplified by the experience of 46 families for 2 to 3 years.

\section{The FAmiLIES}

The 46 families live in a housing estate for new immigrants in Kiryat Yovel, a Jerusalem suburb. They were selected from the 450 families of the estate in the following way. A stratified sample list of every third family was prepared, the original plan having been to study the whole sample. Preliminary examination of the contacts of some thirty families indicated the desirability of limiting the study to a more detailed analysis of a smaller group. Twenty of these thirty families come from North Africa or Near Eastern countries and it was decided to concentrate on this cultural group. The ten families from other countries were dropped and 26 further families with typical North African names were picked out of the stratified list.

These families immigrated during 1950-52 and belong to lower income groups. Their mean size of 4.8 persons (in 1955), rising to 5.5 persons (in 1957 ) is similar to the mean of 5.1 persons for Moroccan families in Israel. Most families consist of parents and young children (Table I); some have only one parent and in some cases the parents are older and the children grown up. Analysis has been confined to the nuclear family, as the few grandparents living with their son's and daughter's families seemed to have a different pattern of morbidity, unrelated to that of the family.
TABLE I

THE 46 FAMILIES, 1955-57, BY AGE AND SEX DISTRIBUTION OF FAMILY MEMBERS

\begin{tabular}{|c|c|c|c|c|c|c|c|c|}
\hline \multirow{3}{*}{$\begin{array}{c}\text { Age } \\
\text { (yrs) }\end{array}$} & \multicolumn{6}{|c|}{ Year } & \multirow{2}{*}{\multicolumn{2}{|c|}{$\begin{array}{c}\text { Total } \\
\text { Person- } \\
\text { Years }\end{array}$}} \\
\hline & \multicolumn{2}{|c|}{$\begin{array}{c}1955 \\
\text { (20 families) }\end{array}$} & \multicolumn{2}{|c|}{$\begin{array}{l}1956 \\
\text { (46 families) }\end{array}$} & \multicolumn{2}{|c|}{$\begin{array}{c}1957 \\
\text { (46 families) }\end{array}$} & & \\
\hline & Male & $\begin{array}{c}\text { Fe- } \\
\text { male }\end{array}$ & Male & $\begin{array}{c}\mathrm{Fe}- \\
\text { male }\end{array}$ & Male & $\begin{array}{c}\text { Fe- } \\
\text { male }\end{array}$ & Male & $\begin{array}{c}\text { Fe- } \\
\text { male }\end{array}$ \\
\hline $\begin{array}{c}0-1 \\
2-4 \\
5-14 \\
15-59 \\
60+\end{array}$ & $\begin{array}{r}5 \\
7 \\
12 \\
26 \\
1\end{array}$ & $\begin{array}{r}5 \\
10 \\
10 \\
19 \\
1\end{array}$ & $\begin{array}{r}13 \\
17 \\
35 \\
61 \\
2\end{array}$ & $\begin{array}{r}81 \\
21 \\
27 \\
56 \\
2\end{array}$ & $\begin{array}{r}7 \\
20 \\
40 \\
61 \\
3\end{array}$ & $\begin{array}{r}8 \\
18 \\
36 \\
57 \\
2\end{array}$ & $\begin{array}{r}25 \\
44 \\
87 \\
148 \\
6\end{array}$ & $\begin{array}{r}21 \\
49 \\
73 \\
132 \\
5\end{array}$ \\
\hline All Ages & 51 & 45 & 128 & 114 & 131 & 121 & 310 & 280 \\
\hline
\end{tabular}

Residents of this housing estate enjoy, together with those of adjacent estates, a high standard of integrated curative-preventive services from the family doctors and nurses of the Hadassah Community Health Centre. Physicians in the Centre record their findings in family files and, in addition, complete a daily consultation sheet (patient's name, age, file number, and diagnosis) for administrative purposes.

\section{Use of the CuRrent Morbidity Records}

Family sheets were prepared from the records, and on these were listed the diagnoses made for each individual member during the year, the number of episodes of disease, and the number of consultations for each diagnosis. For each family, the total number of contacts for all conditions was computed, as well as that for acute respiratory and gastro-intestinal diseases (Annexe I, overleaf). For the first twenty families, the data for 3 years, 1955-57, was extracted

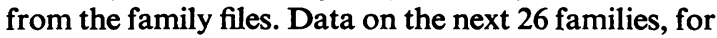
the years 1956-57 only, were taken from the daily consultation sheets of the physicians. There was no significant difference in the mean number of consultations recorded per year in the family files and on 
ANNEXE I

EXAMPLE OF ANNUAL FAMILY SHEET

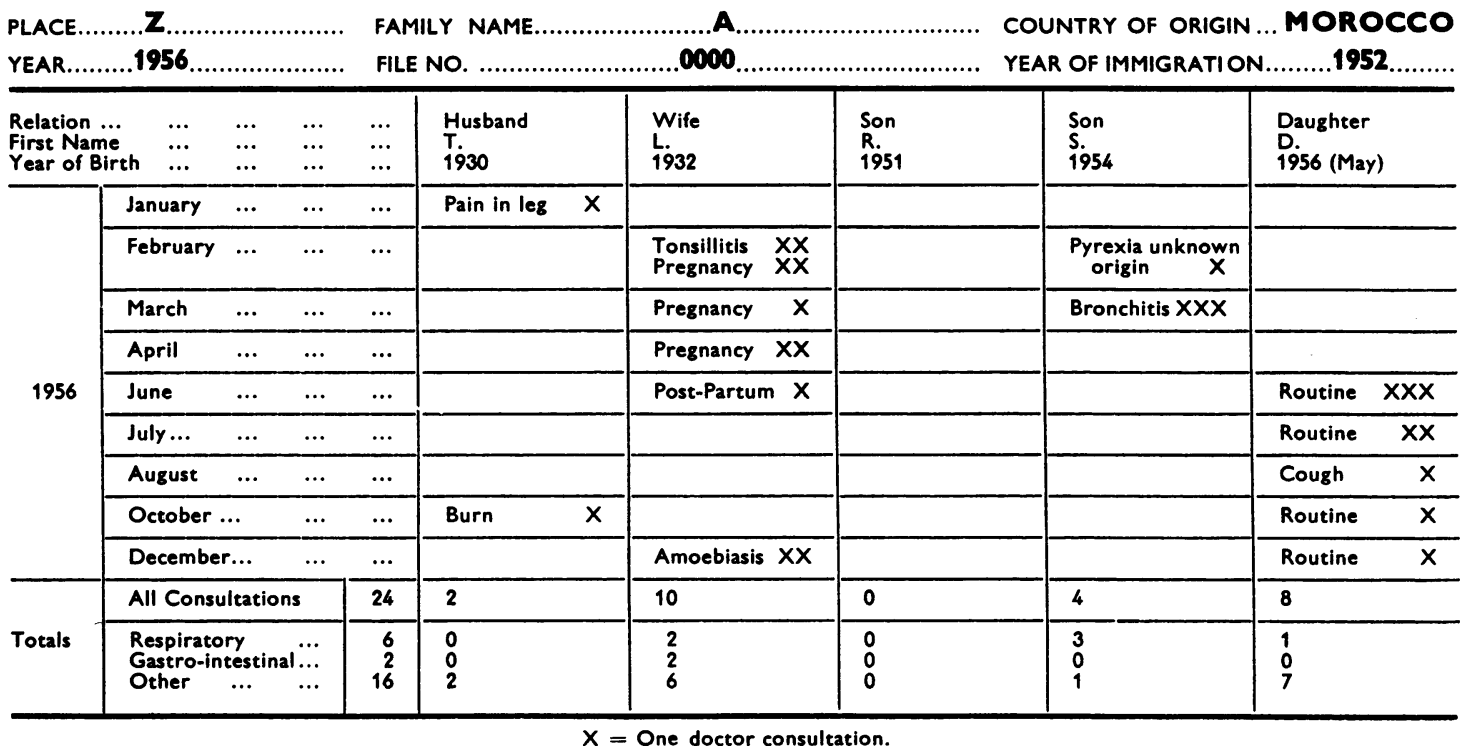

the consultation sheets and it seems permissible to regard these sources as uniform.

Individual data on all consultations and on those for respiratory and gastro-intestinal diseases were grouped by age and sex and the mean rates per year were calculated (Table II). These mean rates were then taken as the expected rates for the particular age-sex group.

Expected consultation rates of members of each family, added up, became the expected rate for that family for that year. This expected family consultation rate changes from year to year with changes in the number of members and in their ages (Annexe IIB, opposite).

The actual number of consultations of individuals and of the family as a whole (Annexe IIA) divided by the expected value, gave consultation-indices for each individual and for each family (Annexe IIC).

TABLE II

THE 46 FAMILIES 1955-57: ANNUAL RATES OF CONSULTATION PER PERSON AND PERCENTAGE OF PERSONS CONSULTING, FOR ALL CONDITIONS, FOR ACUTE RESPIRATORY, AND FOR GASTRO-INTESTINAL DISEASES,

\begin{tabular}{|c|c|c|c|c|c|c|c|c|}
\hline \multirow{2}{*}{ Sex } & \multirow{2}{*}{ Age (yrs) } & \multicolumn{2}{|c|}{ All Consultations } & \multicolumn{2}{|c|}{ Respiratory } & \multicolumn{2}{|c|}{ Gastro-Intestinal } & \multirow{2}{*}{$\begin{array}{c}\begin{array}{c}\text { Other } \\
\text { Conditions }\end{array} \\
\begin{array}{c}\text { Consultations } \\
\text { per } \\
\text { Person }\end{array}\end{array}$} \\
\hline & & $\begin{array}{c}\text { Percentage } \\
\text { Persons } \\
\text { Consulting }\end{array}$ & $\begin{array}{c}\text { Consultations } \\
\text { per } \\
\text { Person }\end{array}$ & $\begin{array}{c}\text { Percentage } \\
\text { Persons } \\
\text { Consulting }\end{array}$ & $\begin{array}{c}\text { Consultations } \\
\text { per } \\
\text { Person }\end{array}$ & $\begin{array}{l}\text { Percentage } \\
\text { Persons } \\
\text { Consulting }\end{array}$ & $\begin{array}{c}\text { Consultations } \\
\text { per } \\
\text { Person }\end{array}$ & \\
\hline \multirow[b]{2}{*}{ Male } & Total & 79 & $5 \cdot 0$ & 55 & $1 \cdot 8$ & 28 & 0.6 & $2 \cdot 5$ \\
\hline & $\begin{array}{c}0-1 * \\
2-4 \\
5-14 \\
15-59 \\
60+* *\end{array}$ & $\begin{array}{l}86) \\
95 \\
79 \\
73 \\
(33)^{* *} \\
\end{array}$ & $\begin{array}{r}19 \cdot 5 \\
7 \cdot 5 \\
3 \cdot 3 \\
3 \cdot 7 \\
(3 \cdot 1)\end{array}$ & $\begin{array}{l}(76)^{*} \\
79 \\
53 \\
46 \\
(17)\end{array}$ & $\begin{array}{l}8 \cdot 1 \\
3 \cdot 3 \\
1 \cdot 2 \\
1 \cdot 0 \\
(0 \cdot 8)\end{array}$ & $\begin{array}{l}(68)^{*} \\
55 \\
19 \\
19 \\
(0)\end{array}$ & $\begin{array}{l}3.5 \\
1.4 \\
0.2 \\
0.3 \\
(0)\end{array}$ & $\begin{array}{l}(7 \cdot 9)^{*} \\
2 \cdot 7 \\
1 \cdot 7 \\
2 \cdot 4 \\
(2-3)^{* *}\end{array}$ \\
\hline \multirow[b]{2}{*}{ Female } & Total & 88 & $7 \cdot 2$ & 61 & $1 \cdot 7$ & 26 & 0.5 & 4.9 \\
\hline & $\begin{array}{c}0-1^{*} \\
2-4 \\
5-14 \\
15-59 \\
60+* *\end{array}$ & $\begin{array}{l}(90)^{*} \\
87 \\
86 \\
89 \\
(80)^{* *}\end{array}$ & $\begin{array}{r}13 \cdot 5 \\
5 \cdot 9 \\
3 \cdot 7 \\
9 \cdot 5 \\
(3 \cdot 0)\end{array}$ & $\begin{array}{l}(62)^{*} \\
77 \\
62 \\
55 \\
(20)^{* *}\end{array}$ & $\begin{array}{l}4 \cdot 4 \\
2 \cdot 2 \\
1 \cdot 7 \\
1 \cdot 4 \\
(0 \cdot 2)\end{array}$ & $\begin{array}{l}(62)^{*} \\
33 \\
157 \\
26 \\
(0)^{* *}\end{array}$ & $\begin{array}{l}2.9 \\
0.6 \\
0.2 \\
0.5 \\
(0)\end{array}$ & $\begin{array}{c}6 \cdot 0 \\
3 \cdot 0 \\
1 \cdot 7 \\
7 \cdot 5 \\
(2 \cdot 8)^{* *}\end{array}$ \\
\hline
\end{tabular}

* The rates for the age group 0-1 years are corrected with regard to the fact that about half of this group were born during a year of study and contributed on the average to only half that year; the percentages of persons consulting are not corrected and therefore represent an * These fieures are based on less than 10 "person-years". 
ANNEXE II

EXAMPLE OF PROFORMA FOR CALCULATION OF INDICES OF ONE FAMILY

\begin{tabular}{|c|c|c|c|c|c|c|c|c|c|c|c|c|c|c|c|c|c|c|c|c|c|c|c|c|c|}
\hline \multirow{3}{*}{ 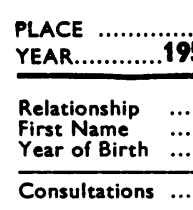 } & \multicolumn{4}{|c|}{$\mathbf{Z}$} & \multicolumn{11}{|c|}{$\begin{array}{l}\text { FAMILY NAME...................... } \\
\text { FILE NO...................000 }\end{array}$} & \multicolumn{10}{|c|}{$\begin{array}{l}\text { COUNTRY OF ORIGIN ........MOROCCO } \\
\text { YEAR OF IMMIGRATION ........1952 } \ldots \ldots \ldots . .\end{array}$} \\
\hline & $\begin{array}{l}\cdots \\
\cdots \\
\cdots\end{array}$ & \multicolumn{4}{|c|}{$\begin{array}{l}\text { Husband } \\
\frac{1930}{T}\end{array}$} & \multicolumn{4}{|c|}{$\frac{\text { Wife }}{1932} \mathrm{~L}$} & \multicolumn{4}{|c|}{$\frac{1}{1951}^{\text {Son }} R$. } & \multicolumn{4}{|c|}{$\frac{\text { Son }}{1954}$ S. } & \multicolumn{4}{|c|}{$\begin{array}{l}\text { Daughter } \\
\overline{1956} \text { (May) }\end{array}$} & \multicolumn{4}{|c|}{ Total Family } \\
\hline & $\cdots$ & $T$ & $\bar{R}$ & $\mathbf{G}$ & 0 & $T$ & $R$ & G & 0 & $T$ & $R$ & G & 0 & $T$ & $R$ & G & 0 & $T$ & $\mathbf{R}$ & G & 0 & $T$ & $\mathbf{R}$ & G & 0 \\
\hline \multirow{4}{*}{$\begin{array}{l}\text { A. Observed } \\
\text { Number of } \\
\text { Consultations }\end{array}$} & 1955 & 0 & 0 & 0 & 0 & 7 & 2 & 0 & 5 & 1 & 1 & 0 & 0 & 7 & 1 & 2 & 4 & & & & & 15 & & & \\
\hline & 1956 & 2 & 0 & 0 & 2 & 10 & 2 & 2 & 6 & 0 & 0 & 0 & 0 & 4 & 3 & 0 & 1 & 8 & 1 & 0 & 7 & 24 & & & \\
\hline & 1957 & 2 & 1 & 0 & 1 & $\overline{11}$ & 1 & 3 & 7 & 0 & 0 & 0 & 0 & 2 & 0 & 0 & 2 & 6 & 3 & 2 & 1 & 21 & & & \\
\hline & Total & 4 & 1 & 0 & 3 & 28 & 5 & 5 & 18 & 1 & 1 & 0 & 0 & 13 & 4 & 2 & 7 & 14 & 4 & 2 & 8 & 60 & 15 & 9 & 36 \\
\hline \multirow{4}{*}{$\begin{array}{l}\text { B. Expected * } \\
\text { Number of } \\
\text { Consultations }\end{array}$} & 1955 & $3 \cdot 7$ & 1 & 0.3 & $2 \cdot 4$ & 9.5 & 1.4 & 0.5 & $7 \cdot 5$ & $7 \cdot 5$ & $3 \cdot 3$ & 1.4 & $2 \cdot 7$ & 19.5 & $8 \cdot 1$ & 3.5 & 7.9 & & & & & $40 \cdot 2$ & & & \\
\hline & 1956 & $3 \cdot 7$ & 1 & 0.3 & $2 \cdot 4$ & 9.5 & 1.4 & 0.5 & 7.5 & $3 \cdot 3$ & 1.2 & 0.2 & $1 \cdot 7$ & $7 \cdot 5$ & $3 \cdot 3$ & 1.4 & $2 \cdot 7$ & $7 \cdot 9$ & $2 \cdot 4$ & $1 \cdot 7$ & $3 \cdot 5$ & 31.9 & & & \\
\hline & 1957 & $3 \cdot 7$ & 1 & 0.3 & $2 \cdot 4$ & 9.5 & 1.4 & 0.5 & $7 \cdot 5$ & $3 \cdot 3$ & $1 \cdot 2$ & 0.2 & $1 \cdot 7$ & $7 \cdot 5$ & $3 \cdot 3$ & 1.4 & $2 \cdot 71$ & 13.5 & $4 \cdot 4$ & $2 \cdot 5$ & 6.0 & $37 \cdot 5$ & & & \\
\hline & Total & $11 \cdot 1$ & 3 & 0.9 & $7 \cdot 2$ & $28 \cdot 5$ & $4 \cdot 2$ & 1.5 & $22 \cdot 5$ & $14 \cdot 1$ & $5 \cdot 7$ & 1.8 & $6 \cdot 1=$ & $34 \cdot 5$ & $14 \cdot 1$ & $6 \cdot 31$ & $\overline{13.3} \sqrt{2}$ & $21 \cdot 4$ & $6 \cdot 8$ & 4.6 & $9 \cdot 5$ & $109 \cdot 6$ & 34.4 & $15 \cdot 1$ & 58.6 \\
\hline \multirow{4}{*}{ C. Indices A/B } & 1955 & & & & & & & & & & & & & & & & & & & & & 0.4 & & & \\
\hline & 1956 & & & & & & & & & & & & & & & & & & & & & 0.8 & & & \\
\hline & 1957 & & & & & & & & & & & & & & & & & & & & & 0.6 & & & \\
\hline & Total & 0.4 & & & & 1 & & & & 0.1 & & & & 0.4 & & & & 0.7 & & & & 0.5 & 0.4 & 0.6 & 0.6 \\
\hline
\end{tabular}

- Expected according to Table of Averages of consultations by age and sex, for children born during the year, with correction according to number of months alive in that year.

In this way, the following indices were calculated:

(1) For each Individual:

All consultations during the whole period.

(2) For each Family:

(a) All consultations for every year;

(b) Consultations for respiratory diseases for the whole period;

(c) Consultations for gastro-intestinal diseases for the whole period;

(d) All consultations (other than $b$ and $c$ ) for the whole period.

\section{APPLICATION OF INDICES}

Three illustrative questions may be asked to indicate the use of the indices:

(1) Have members of a family a common trend in the numbers of their individual consultations?

The distribution of individual indices by family for the 46 families is shown in Fig. 1. The following points were observed:

Nine with all individual indices below $1 \cdot 0$.

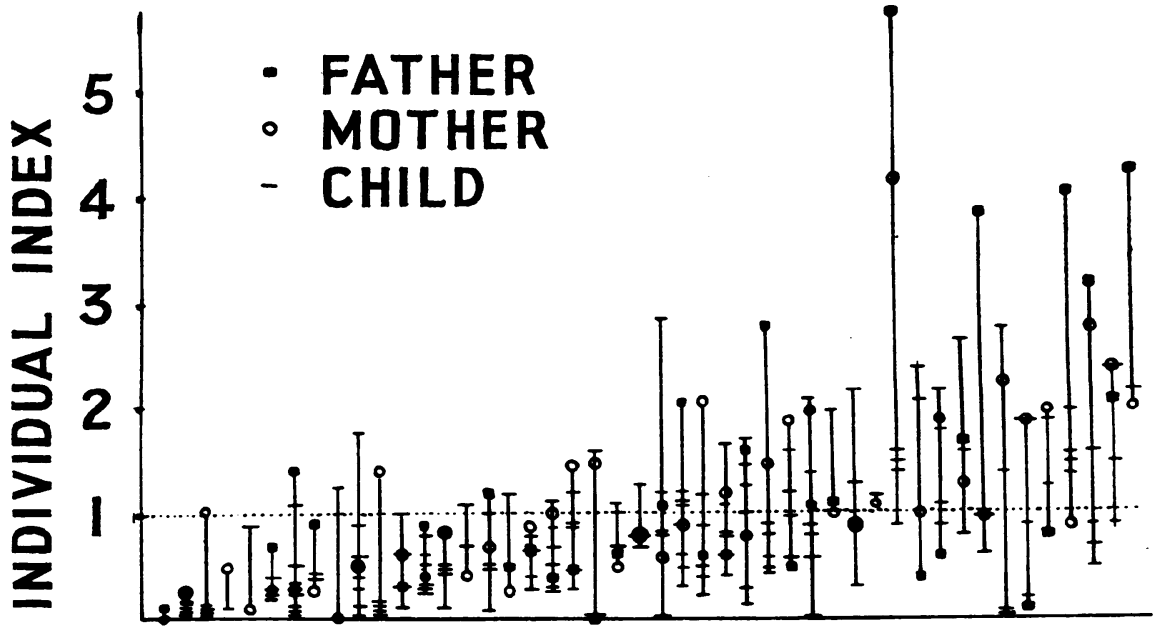

Each line represents one family

FIG. 1.-Distribution of individual indices by family (total consultation). 
Two with all individual indices above $1 \cdot 0$.

Of 35 families whose indices crossed the 1.0 line:

Eight had all individual indices within an interval of one index unit.

Twenty had two-thirds or more of their indices within the space of one unit.

Seven remaining showed more divergent values.

(2) Has a family a constant trend in the pattern of its consultations over the years?

Fig. 2 shows the correlation of the indices of the first twenty families for 1955 and 1956 and for all 46 families for 1956 and 1957.

The corresponding coefficient of correlation is $r=+0.85$ for $1955-56$ and $r=+0.45$ for 1956-7.

The distribution of the annual indices of each family is illustrated in Fig. 3.
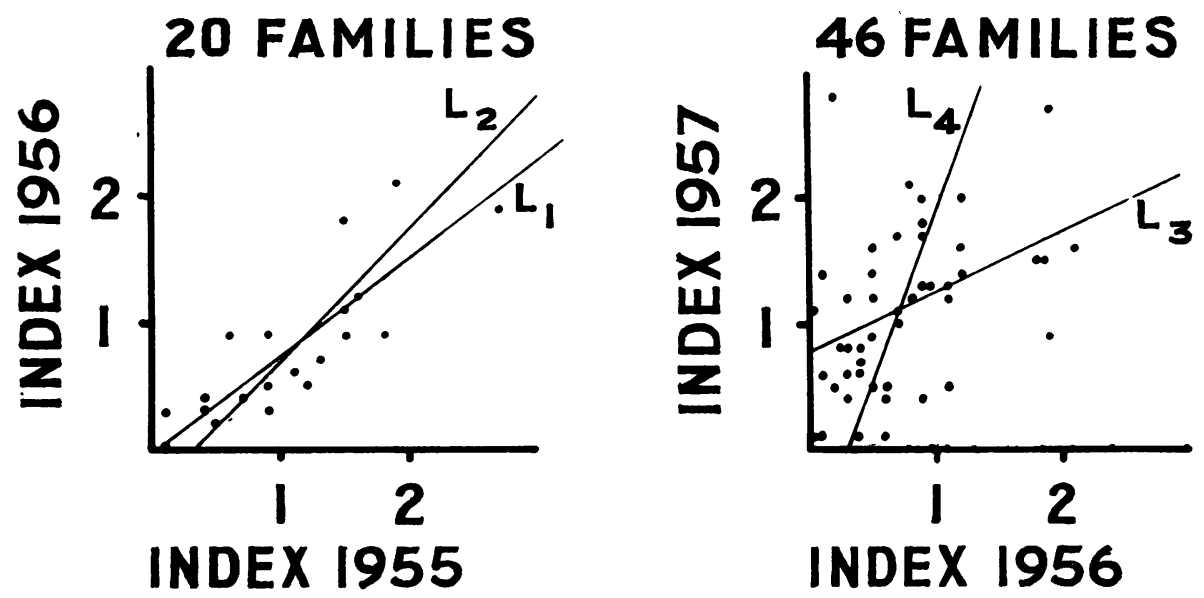

$$
\begin{array}{llll}
\mathrm{L}_{2} & y=0.79+0.75(x-1.08) & \mathrm{L}_{4} & y=1.11+0.54(x-0.73) \\
\mathrm{L}_{2} & x=1.08+0.96(y-0.79) & \mathrm{L}_{4} & x=0.73+0.37(y-1.11)
\end{array}
$$

FIG. 2.-Distribution of annual family indices by year (total consultation).

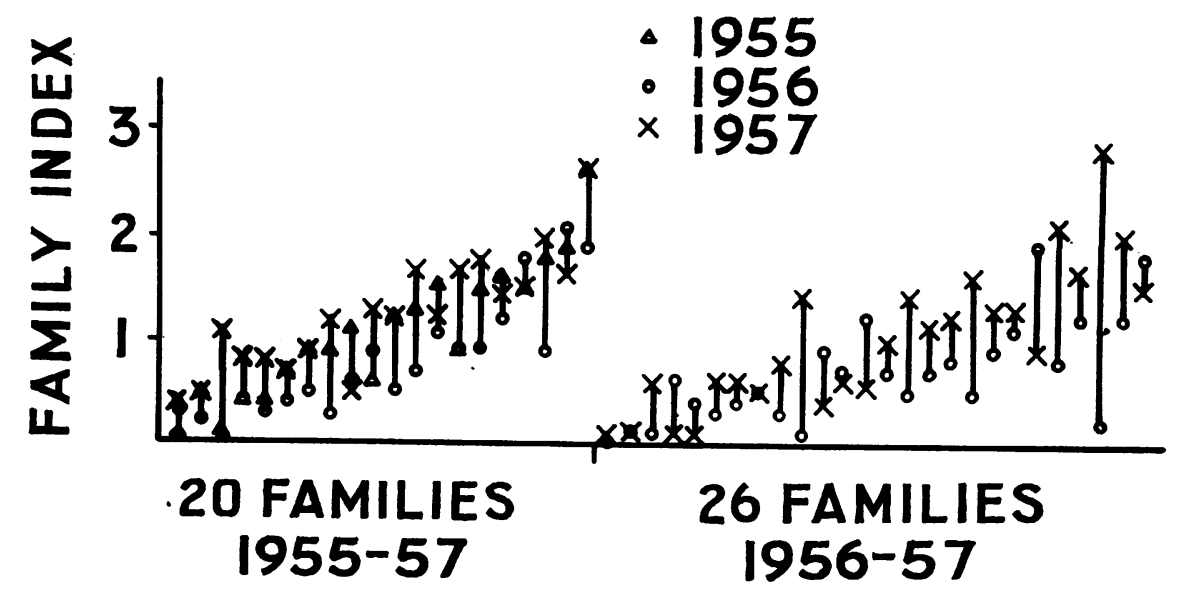

Each line represents one family

Fig. 3.-Correlations between family indices for different diagnostic groups. 


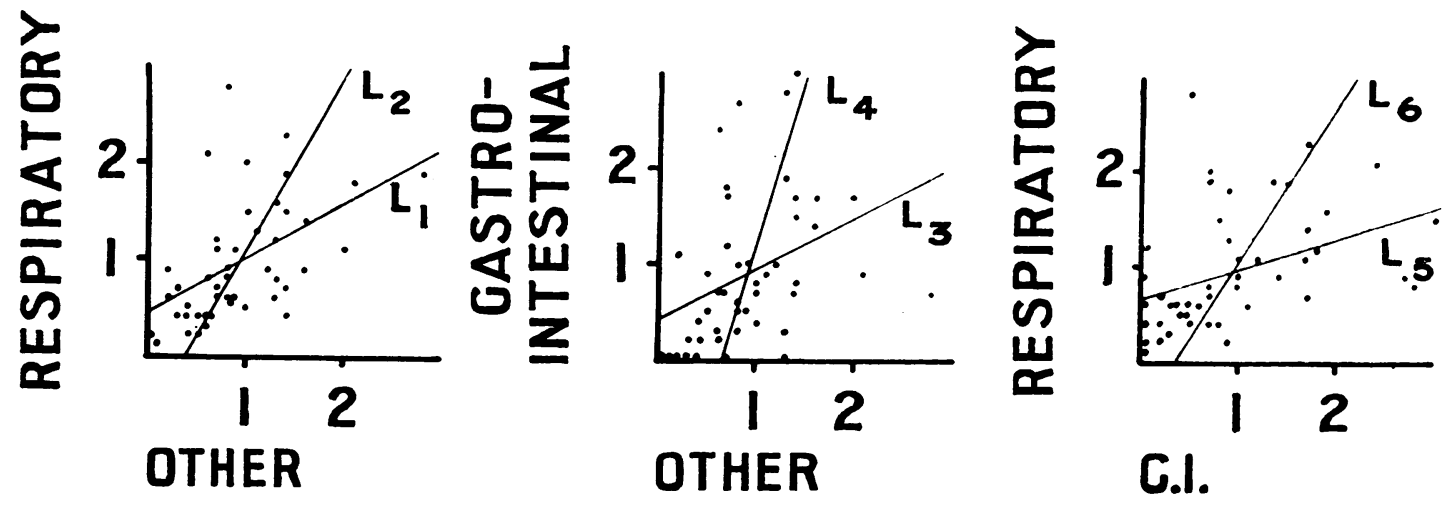

Equations of Lines of Regression

$$
\begin{array}{llll}
\mathrm{L}_{1} & y=0.95+0.58(x-0.92) & \mathrm{L}_{4} & x=0.92+0.27(y-0.91) \\
\mathrm{L}_{2} & x=0.92+0.56(y-0.95) & \mathrm{L}_{5} & y=0.95+0.30(x-0.91) \\
\mathrm{L}_{3} & y=0.91+0.53(x-0.92) & \mathrm{L}_{6} & x=0.91+0.58(y-0.95)
\end{array}
$$

FIG. 4.-Correlation between family indices for different years (total consultation).

(3) Are there "consultation-prone" families, independent of specific disease groups?

Certain correlations for the 46 families are illustrated in Fig. 4.

The correlation coefficient for the family indices between consultations for respiratory and gastro-intestinal diseases is $r=+0.42$, between respiratory and all other diseases is $r=+0.57$, and between gastro-intestinal and all other diseases is $r=+0 \cdot 37$.

\section{COMMENT}

The purpose of this paper is to illustrate an approach to the measurement of family morbidity data rather than to answer specific questions. The method has been worked out for a small number of families by way of demonstration. There may well be no general answer to such questions, the results differing with family circumstances.

Family indices of morbidity may be used for picking out particular groups for further study or for special care, e.g. those with high or low consultation rates for a specific disease or for all diseases.

This method may also be used in the study of individual morbidity by comparing individual indices for various diagnoses and looking for correlations between them.

Thanks are due to the staff of the Hadassah Community Health Centre, Kiryat Yovel, particularly to Dr. Charlotte Kaplan, Acting Director, and Mrs. Ruth Behrens, Recorder, for their interest and help. 